\title{
Checklist of Leaf beetles of Navsari Agricultural University, Navsari, Gujarat, India
}

\author{
Rahul Debbarma* and Sachin R. Patel
}

Department of Agricultural Entomology, N.M.C.A, NAU, Navsari, India

*Corresponding author

\section{A B S T R A C T}

\section{Keywords}

Leaf beetles, Alticinae,

Criocerinae,

Navsari

Agricultural

University

Article Info

Accepted:

18 August 2020

Available Online:

10 September 2020
An investigation on biodiversity of leaf beetles was carried out at N. M. College of Agriculture, Navsari Agricultural University (NAU) campus Navsari, Gujarat, India during 2018-19. A total 14 species of Leaf beetles were recorded belonging to 11 genera and 6 subfamilies viz., Alticinae, Cassidinae, Criocerinae, Eumolpinae, Galerucinae and Hispinaefrom different ecosystems i.e., paddy, bottle gourd, cruciferous crops, sponge gourd, sweet potato, okra and surya vartiplant (Chrozophora rottleri). Among them $21.43 \%$ belongs to Alticinae and Criocerinae each whereas Cassidinae, Eumolpinae, Galerucinae and Hispinae constitute $14.29 \%$ each and prepared the pictorial checklist of 14 species of leaf beetles was prepared.

\section{Introduction}

Insects are very important part of human life. They are considered as pests of many crops and had a great economic importance. Among various insect pests, the order Coleoptera (beetles and weevils) are considered as very important group. Among the Coleoptera the insects of the family Chrysomelidae are commonly known as leaf beetles, which includes over 35,000 species and more than 2,000 genera distributed worldwide except in the arctic regions and is one of the largest and most commonly encountered among all the beetle families (Jolivet et al., 2009; Thormann et al., 2016). Leaf beetles are the most abundant and harmful coleopteran pests of vegetables and show diverse adaptations to wide range of environmental conditions and habitats. They are also highly specialized insects feeding on a wide range of plant groups and are important both ecologically and economically due to their worldwide distribution and distinct host range. To fill up the gaps in knowledge about different species of leaf beetles with their photographic catalogue in NAU campus, the present study was done. 


\section{Materials and Methods}

A study was carried out at N. M. College of Agriculture, Navsari Agricultural University (NAU) campus, Navsari, Gujarat, India from March 2018 to December 2018 under different agroecosystems. The ecosystems that are likely to support the leaf beetles in the study area such as paddy, bottle gourd, cruciferous crops, sponge gourd, sweet potato, okra and suryavarti plant (Chrozophora rottleri) were searched for leaf beetles. When leaf beetles are observed they are photographed and collected by the handpicking method. The unidentified leaf beetle specimens were sent to Dr. K. D. Prathapan, Professor, Department of Entomology, College of Agriculture, Kerala Agricultural University, Vellayani, Trivandrum, Kerala. The pictorial checklist is a useful tool for the identification of leaf beetlesin the state. Therefore, close up photographs of species and their behavioral patterns were captured with the help of digital camera. Live specimens from the field conditions were photographed, so that natural colouration and specific behavioural postures can be documented. The picture of small leaf beetles was taken by dissecting stereo-trinocular microscope having SCAPE software.

\section{Results and Discussion}

During the present study a total of 14 leaf beetle species were recorded from different ecosystems, belonging to 6subfamilies. Among them $21.43 \%$ belongs to Alticinae and Criocerinae each whereas Cassidinae, Eumolpinae, Galerucinae and Hispinae constitute $14.29 \%$ each (Table 1 and Fig. 1). Basu et al., (1981) recorded 25 species spread over 12 genera under 6 subfamilies from Tripura. Pawara et al., (2012) recorded two Chrysomelid beetle species viz., Callosobruchus maculates (Fabricius, 1775) and C.chinensis (Linn, 1758) from Jalgaon district of Maharashtra, India. Arya et al., (2016) recorded 5 species of Chrysomelidae in different elevational zones of Binsar Wildlife Sanctuary, Almora, Uttarakhand, India.

During the present study, the subfamilies recorded were Alticinae (3 spp.), Cassidinae (2 spp.), Criocerinae (3 spp.), Eumolpinae (2 spp.), Galerucinae (2 spp.) and Hispinae (2 spp.). In the present study Alticinae (3 genera) and Criocerinae ( 2 genera) was the most dominant subfamily comprising of 3 species each with 21.43 per cent species distribution. Kalaichelvan and Verma (2005) prepared a checklist of total 95 species, belonging to 10 subfamilies from Bhilai-Durg (Central India). The subfamilies include Criocerinae (10 spp.), Clytrinae (6 spp.), Cryptocephalinae (8 spp.), Chlamisinae (1 sp.), Eumolpinae (6 spp.), Chrysomelinae (4 spp.), Galerucinae (15 spp.), Alticinae (23 spp.), Hispinae (4 spp.), and Cassidinae (18 spp.).

Table.1 Species distribution of leaf beetles of different subfamilies in the NAU, Navsari campus

\begin{tabular}{|c|l|r|c|c|}
\hline Sr. No & Subfamily & Genera & No. of species & Species \% \\
\hline $\mathbf{1 .}$ & Alticinae & 3 & 3 & 21.43 \\
\hline $\mathbf{2 .}$ & Cassidinae & 2 & 2 & 14.29 \\
\hline $\mathbf{3 .}$ & Criocerinae & 2 & 3 & 21.43 \\
\hline $\mathbf{4 .}$ & Eumolpinae & 1 & 2 & 14.29 \\
\hline $\mathbf{5 .}$ & Galerucinae & 1 & 2 & 14.29 \\
\hline $\mathbf{6 .}$ & Hispinae & 2 & 2 & 14.29 \\
\hline & Total & $\mathbf{1 1}$ & $\mathbf{1 4}$ & $\mathbf{1 0 0}$ \\
\hline
\end{tabular}


Table.2 Pictorial checklist of leaf beetle species (Chrysomelidae) of NAU, Navsari campus

\begin{tabular}{|c|c|c|}
\hline $\begin{array}{l}\text { Sr. } \\
\text { No. }\end{array}$ & Leaf beetle species & Habitat \\
\hline 1. & Hermaeophaga ruficollis(Lucas, 1849) & Suryavarti (Chrozophora rottleri) \\
\hline 2. & Phyllotreta cruciferae (Goeze, 1777) & $\begin{array}{l}\text { Cruciferous vegetables viz., } \\
\text { mustard, radish, cabbage and } \\
\text { cauliflower }\end{array}$ \\
\hline 3. & Podagrica sp. & $\begin{array}{l}\text { Okra and other allied plants of the } \\
\text { same family Malvaceae }\end{array}$ \\
\hline 4. & Cassida circumdata (Herbst, 1799) & Sweet potato \\
\hline 5. & Chiridopsis bipunctata (Linnaeus, 1767) & Sweet potato \\
\hline 6. & Lema sp.1 & Paddy ecosystem \\
\hline 7. & Lema sp. 2 & Paddy ecosystem \\
\hline 8. & Oulema melanopus (Linnaeus, 1758) & Paddy ecosystem \\
\hline 9. & Colasposoma sp.1 & Sweet potato \\
\hline 10. & Colasposoma sp.2 & Sweet potato \\
\hline 11. & Aulacophora foveicollis (Lucas, 1849) & Cucumber and Bottle gourd \\
\hline 12. & Aulacophora lewisii (Baly, 1886) & Sponge gourd \\
\hline 13. & Chaeridiona picea (Baly, 1869) & Paddy Ecosystem \\
\hline 14. & Dicladis paarmigera (Oliver, 1808) & Paddy Ecosystem \\
\hline
\end{tabular}

Fig.1 Distribution of different subfamilies of Chrysomelidae

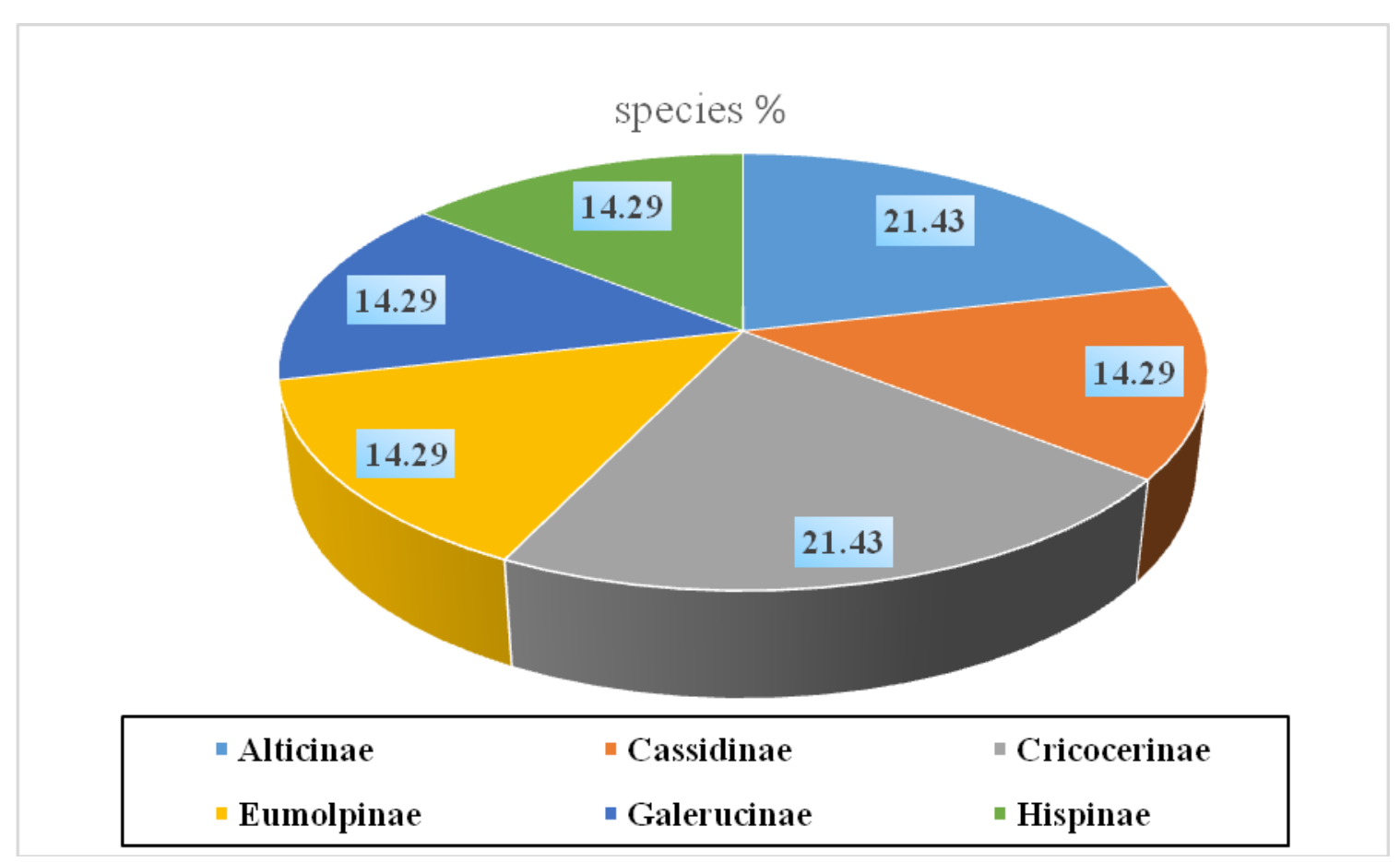




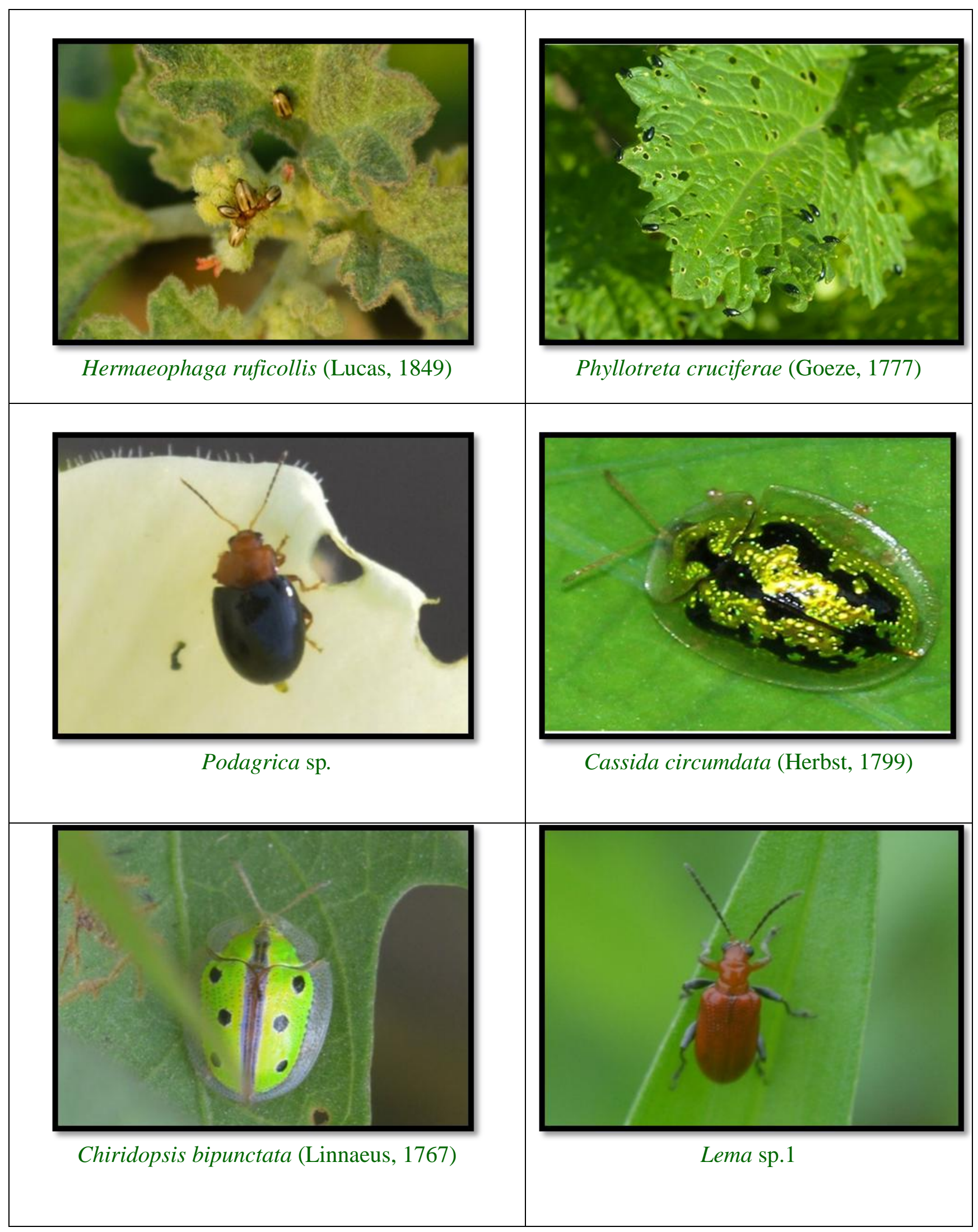




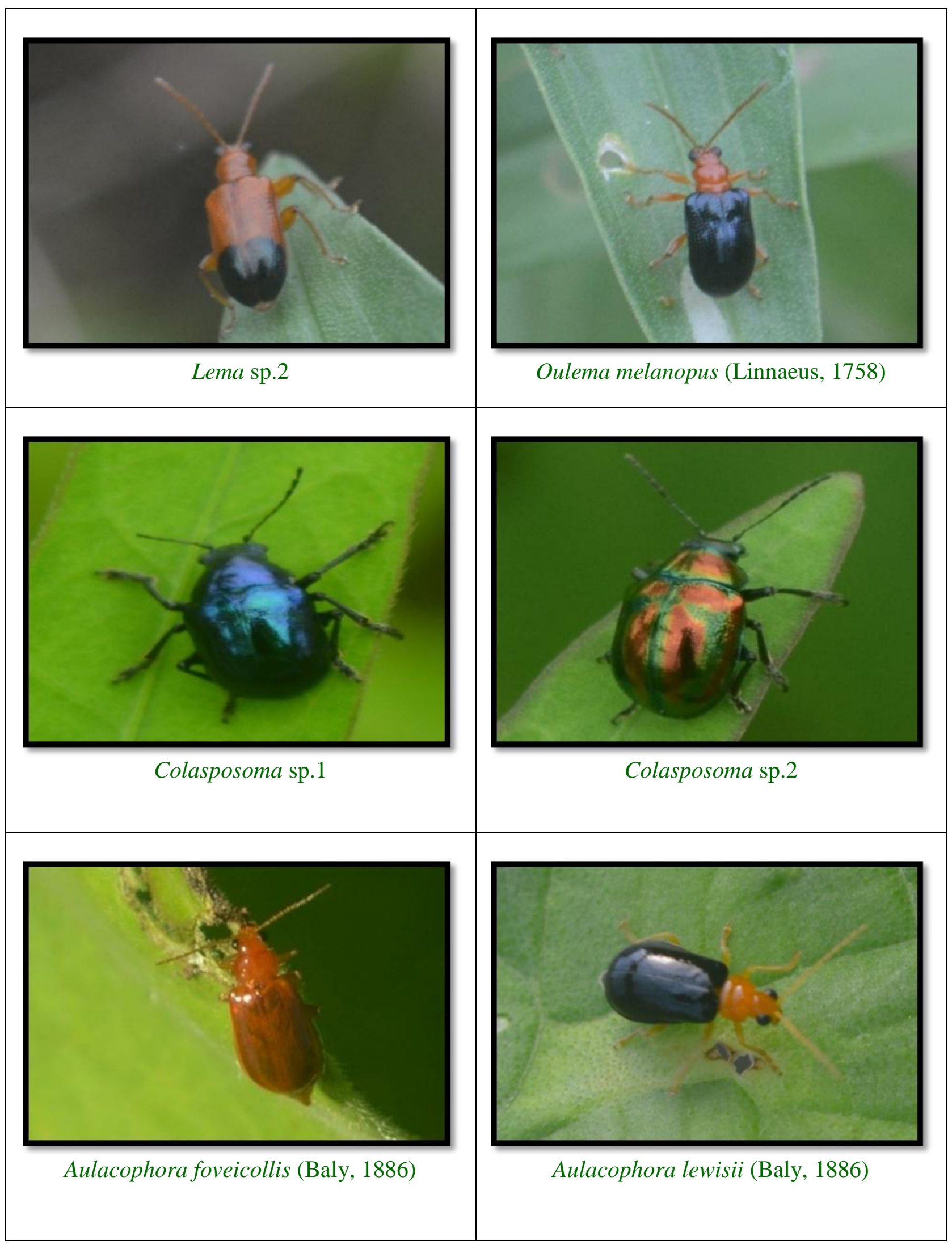




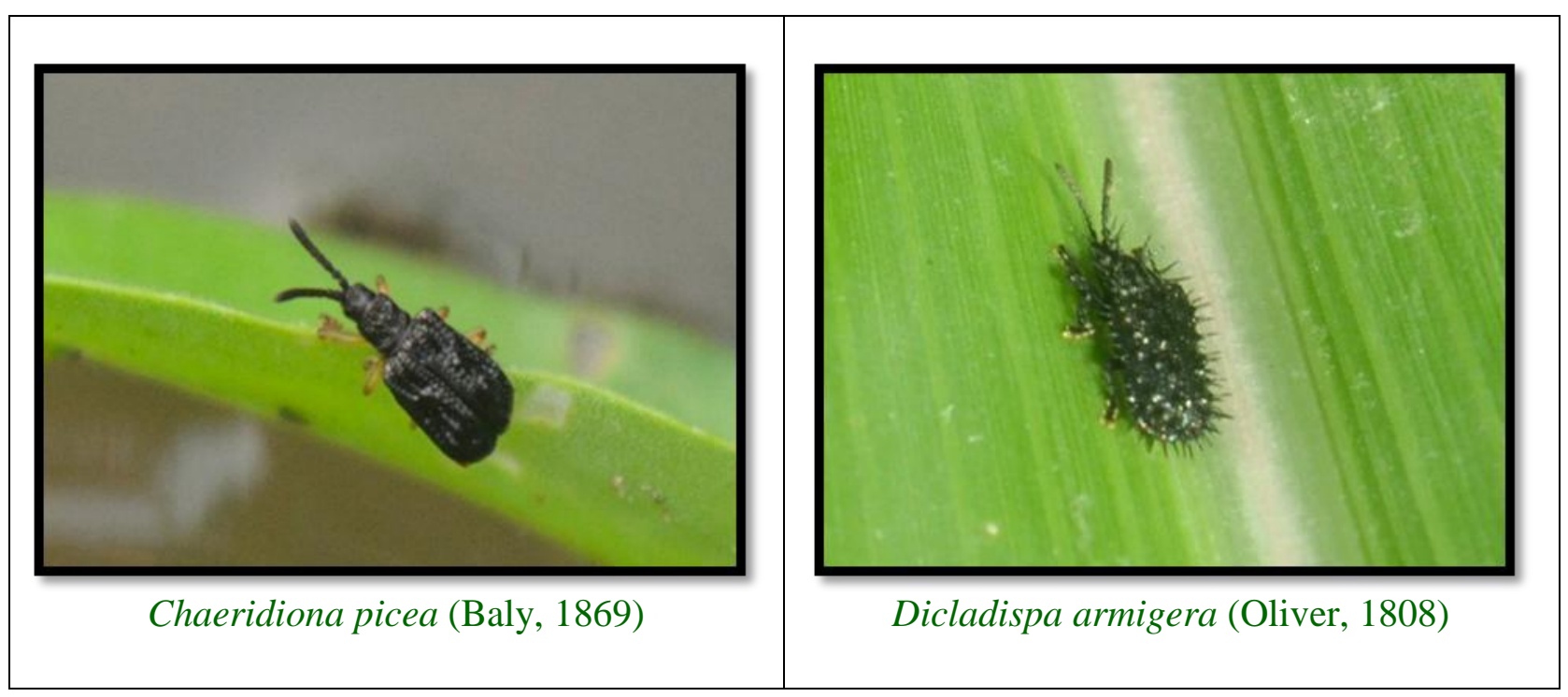

In the present investigation, a total of 14 species of leaf beetles in 11 genera belonging to 6subfamilies were recorded and the pictorial checklist of different leaf beetles from NAU, Navsari campus was prepared (Table 2).

The checklist of the Chrysomelidae of different countries/continents/ecozones were published in recent past by several authors, Baselga and Novoa (2002), Lopatin et al., (2003), Mohamedsaid (2004), Andrews and Gilbert (2005), Kalaichelvan and Verma (2005), Petitpierre (2005), Bardin and Timraleev (2007), Barney et al., (2007), Ekiz et al., (2013), Alekseeva and Bukejs (2014), Baviera and Biondi (2015), Borowiec and Świętojańska (2015), Gajendra and Prasad (2016), Maican and Serafim (2016), Maican and Serafim (2017), Nie et al., (2017), Rodríguez-Mirón (2018), Maican and Serafim (2018) and Moseyko et al., (2018). The present compilation was also more or less similar in accordance with the earlier checklist, as most of the subfamilies and species were found in these checklists. In the present study the leaf beetle subfamilies Alticinae, Cassidinae, Criocerinae, Eumolpinae, Galerucinae and Hispinaewere commonly found in Navsari Agricultural University, Navsari, Gujarat, India.

In conclusion, the pictorial checklist was prepared of total 14 species of leaf beetles which belongs to 11 genera and 6subfamilies from different habitats with their taxonomic position.

\section{Acknowledgement}

The authors are thankful to Dr. K. D. Prathapan, Professor, Department of Entomology, College of Agriculture, Kerala Agricultural University, Vellayani, Trivandrum, Kerala for identifying the leaf beetle species and his valuable suggestions.

\section{References}

Alekseev, V. I., and Bukejs, A. (2014). An annotated catalogue of leaf beetles (Coleoptera: Megalopodidae, Orsodacnidae, and Chrysomelidae) of the Kaliningrad Region (Russia). Zoology and Ecology, 24(3): 219-238.

Andrews, F. G. and Gilbert, A. J. (2005). A preliminary annotated checklist and evaluation of the diversity of the 
Chrysomelidae (Coleoptera) of the Baja California peninsula, Mexico. Insecta Mundi, 19: 1-2.

Arya, M. K., Tamta, P. and Dayakrishna (2016). Study on Distribution and Diversity of Beetles (Insecta: Coleoptera) in Different Elevational Zones of Binsar Wildlife Sanctuary, Almora, Uttarakhand, India. Journal of Entomology and Zoology Studies,4(4): 311-316.

Bardin, O. D., and Timraleev, Z. A. (2007). A contribution to the fauna and ecology of leaf beetles (Coleoptera, Chrysomelidae) in the Republic of Mordovia. Entomological Review, 87(6): 670-676.

Barney, R. J., Clark, S. M., and Riley, E. G. (2007). Annotated List of the Leaf Beetles (Coleoptera: Chrysomelidae) of Kentucky: Subfamily Cassidinae. Journal of the Kentucky Academy of Science, 68(2): 132-144.

Baselga, A., and Novoa, F. (2002). Los Chrysomelidae (Coleoptera) de las sierras orientales de Ourense (Galicia, Noroestede la Península Ibérica). Boletín de la Asociaciónespañola de Entomología, 26(3-4): 57-73.

Basu, C. R., Bhaumik, A. R., and Sengupta, T. (1981). Chrysomelidae (Coleoptera) of Tripura (India). Records of the Zoological Survey of India, 78: 41-61.

Baviera, C., and Biondi, M. (2015). The Alticini (Coleoptera: Chrysomelidae, Galerucinae) of Sicily: recent records and updated checklist. Attidella Accademia Peloritanadei PericolantiClasse di Scienze Fisiche, Matematiche e Naturali, 93(2): 2.

Borowiec, L., and Świętojańska, J. (2015). Checklist of tortoise beetles (Coleoptera, Chrysomelidae, Cassidinae) from Colombia with new data and description of a new species. ZooKeys, 518: 87.
Ekiz, A. N., Şen, İ., Aslan, E. G., and Gök, A. (2013). Checklist of leaf beetles (Coleoptera: Chrysomelidae) of Turkey, excluding Bruchinae. Journal of Natural History, 47(33-34): 2213-2287.

Gajendra, M., and. Prasad S. K. (2016). A Review of Coleoptera Diversity of Chhattisgarh: Updated Checklist 2015, International Journal of Science and Research (IJSR), 5(4): 710-714.

Jolivet, P., Santiago-Blay, J., and Schmitt, M. (2009). Research on Chrysomelidae, Vol. 2. Brill, Leiden, 1:300.

Kalaichelvan, T., and Verma, K. K. (2005). Checklist of leaf beetles (Coleoptera: Chrysomelidae) of Bhilai-Durg. Zoos' Print Journal, 20(4): 1838-1842.

Lopatin, I., Chikatunov, V., and Pavlíček, T. (2003). Catalogue of the beetles (Coleoptera) in Israel and adjacent areas: 3. Chrysomelidae (except Alticinae). Zoology in the Middle East, 28(1): 87-112.

Maican, S., and Serafim, R. (2016). The Catalogue of Donaciinae and Criocerinae Species (Coleoptera: Chrysomelidae) from the New Leaf Beetle Collection from "GrigoreAntipa" National Museum of Natural History (Bucharest) (Part I). Travaux $d u$ Muséum National d'Histoire Naturelle “GrigoreAntipa”, 59(2): 179-194.

Maican, S., and Serafim, R. (2017). Catalogue of Cassidinae (Coleoptera: Chrysomelidae) from the New Leaf Beetles Collection from "GrigoreAntipa" National Museum of Natural History (Bucharest)(Part II). Travaux $d u$ Muséum National d'HistoireNaturelle "GrigoreAntipa", 60(2): 477-494.

Maican, S., and Serafim, R. (2018). Catalogue of Chrysomelini species (Coleoptera: Chrysomelidae: Chrysomelinae) from the new leaf beetles collection of "Grigore Antipa" national museum of 
natural history (Bucharest) (part III). Travaux du Muséum National d'Histoire Naturelle "Grigore Antipa", 61(1): 23-42.

Mohamedsaid, M. S. (2004). Catalogue of the Malaysian Chrysomelidae (Insecta: Coleoptera). European Journal of Entomology. 101: 628

Moseyko, A. G., Ponomarev, K. B., Teploukhov, V. Y., and Knyazev, S. A. (2018). A Review of the Leaf-Beetle Fauna (Coleoptera, Chrysomelidae sensulato) of Omsk Province. Entomological Review, 98(8): 10641087.

Nie, R. E., Bezděk, J., and Yang, X. K. (2017). How many genera and species of Galerucinae s. str. do we know? Updated statistics (Coleoptera, Chrysomelidae). ZooKeys, 720:91-102

Pawara, R. H., Patel, N. G., Pawara, J. V.,
Gavit, P. J., and Ishi, S. S. (2012). Beetles of Jalgaon district of Maharashtra, India. BiolifeAn International Quarterly Journal of Biology \& Life Sciences, 2(3): 970-973.

Petitpierre, E. (2005). List of Chrysomelidae (Coleoptera) of Asturias and Cantabria. Boln. Asoc. Esp. Ent, 29: 5172.

Rodríguez-Mirón, G. M. (2018). Checklist of the family Megalopodidae Latreille (Coleoptera: Chrysomeloidea); a synthesis of its diversity and distribution. Zootaxa, 4434(2): 265-302. Thormann, B., Ahrens, D., Armijos, D. M., Peters, M. K., Wagner, T., and Wägele, J. W. (2016). Exploring the leaf beetle fauna (Coleoptera: Chrysomelidae) of an Ecuadorian mountain forest using DNA barcoding. PloS one, 11(2), e0148268.

\section{How to cite this article:}

Rahul Debbarma and Sachin R. Patel. 2020. Checklist of Leaf beetles of Navsari Agricultural University, Navsari, Gujarat, India. Int.J.Curr.Microbiol.App.Sci. 9(09): 2717-2724. doi: https://doi.org/10.20546/ijcmas.2020.909.338 